\title{
Formulation and Standardization of Pregame Supplements
}

\author{
A. Ananthalakshmi ${ }^{1 *}$ and G. Vasanthamani ${ }^{2}$ \\ ${ }^{1}$ Associate Professor in Home Science, Queen Mary's College, Chennai - 600004, Tamil Nadu, India \\ 2Professor and Head (retired), Department of FSMD, Avinashilingam Institute for Home Science and Higher \\ Education for Women, Coimbatore - 641043, Tamil Nadu, India
}

\begin{abstract}
A food based approach would be a practical solution in addressing the poor performance and nutritional anemia which could provide immediate relief to our budding sports persons belonging to low income category. Formulation and standardization of pregame supplements utilizing locally available, low cost ingredients utilizing indigenous methods of preparations would pave path for the enhancement of performance capabilities of athletes. Hence an attempt was made to formulate and standardize pregame supplements.
\end{abstract}

\section{Introduction}

Globally sports and athletics receive much attention today. The sports industry is growing by leaps and bounds. India is making rapid strides in the field of sports. Indian athletes are endeavoring their best to top in the national and international arena. Their performance is often obstructed by lack of stamina and poor health due to nutritional deficiencies and disorders. Moreover, lack of grass root level sports and training, poor stature, poor sub optimal diet, poor knowledge and understanding about sports nutrition are the causes of poor performance. Physical fitness is one of the richest possessions. It cannot be purchased and has to be earned through a daily routine of right diet and physical exercise. Optimal physical fitness aids to look better, feel better and experience good health, leading to high quality of life. It is an inseparable part of sports performance and achievement. It brings success, helps to withstand stress and strain caused by sports and prevents injuries. Physical fitness is associated with a person's ability to work effectively, enjoy leisure time, be healthy, resist hypokinetic diseases or conditions. Feeding of the athletes with nutritious supplements prior to an event would enhance the strength, stamina and performance capabilities. A food based approach would be a practical solution in addressing the poor performance and nutritional anaemia which could provide immediate relief. Hence, the present study on formulation and standardization of pregame supplements was carried out.

\section{Materials and Methods}

The present research was carried out in Chennai city in Tamil Nadu, India. As the study involved female athletes participating in sports and games, institutions which had well established sports and games departments were identified. Thus, three colleges namely Queen Mary's College (QMC), Quaid-e-Millath Government College for Women (QMGCW) and Ethiraj College for Women (ECW) were selected for the study.

Study sample for the present research included 530 female athletes in the age group of 18 to 24 years, who

${ }^{*}$ Author for correspondence 
were young adults, in their prime productive stage. Complete enumeration was used in the selection of subjects. Socio-economic status and nutritional status were assessed for all the selected 530 athletes. From this 530 athletes a subsample of 100 athletes were selected by judgment sampling method for evaluating the endurance capabilities. Assessment of nutritional status and performance capabilities of selected athletes pointed out the need for enhancing the health status and endurance capacity of the sports persons and athletes. Due to low income, poor purchasing power and lack of low cost pregame supplements the selected athletes showed poor performance capabilities. Sridevi and Sarojini, $\stackrel{1}{-}$ have pointed out that supplementation may be designed with the locally available, cost effective ingredients to improve the situation.

Indian Science Congress $\underline{2}$ focal theme emphasized that the products suited to Indian needs can be designed and developed indigenously. Karnik ${ }^{3}$ had pointed out that iron fortified foods such as cereals can be a good way to get iron along with carbohydrates needed to fuel the training. Rice, wheat and millets are the main cereal grains that are cheapest sources of calories. $\mathrm{FAO}^{4}$ had declared that cereal based foods are the most important sources of nutrients for the mankind.

Hence keeping cereals and millets as the main ingredients several permutations and combinations were examined and final combinations of three types of nutrimix powders were developed. These variations had red rice (Oryza sativa), sago (Manihot esculenta), roasted Bengal gram dhal (Cicer arietinum), green gram dhal (Phaseolus aures Roxb), gingelly seeds (Sesamum indicum), niger seeds (Guizotia abyssinica) and peanuts (Arachis hypogaea) as common ingredients. The type of millet was changed and three different variations of nutrimix powders were developed. Variation I (V1) had ragi (Eleusine coracana), variation II (V2) had the millet jowar (Sorghum vulgare) and variation III (V3) had bajra (Pennisetum typhoideum). All the ingredients were roasted till the acceptable aroma arose, cooled and powdered in the flour mill.

\subsection{Shelf Life}

The formulated nutrimix powder was examined initially, periodically after every 15 days and after a storage period of three months for their microbial content. Standard plate count, yeast and mould count were carried out.

The composition of the three variations of the nutrimix powders developed is given in (Table 1).

Table 1. Composition of the three variations of nutrimix powders formulated

\begin{tabular}{|c|c|c|c|}
\hline Variations & Ingredients & $\begin{array}{l}\text { Quantity } \\
\text { (g) }\end{array}$ & $\begin{array}{c}\text { Total Weight } \\
\text { (g) }\end{array}$ \\
\hline $\mathrm{V}_{1}$ & $\begin{array}{l}\text { Red rice } \\
\text { Sago } \\
\text { Roasted } \\
\text { Bengal gram } \\
\text { dhal } \\
\text { Green gram } \\
\text { dhal } \\
\text { Gingelly } \\
\text { seeds } \\
\text { Peanuts } \\
\text { Niger seeds } \\
\text { Ragi }\end{array}$ & $\begin{array}{l}100 \\
100 \\
100 \\
100 \\
30 \\
30 \\
30 \\
100\end{array}$ & 590 \\
\hline $\mathrm{V}_{2}$ & $\begin{array}{l}\text { Red rice } \\
\text { Sago } \\
\text { Roasted } \\
\text { Bengal gram } \\
\text { dhal } \\
\text { Green gram } \\
\text { dhal } \\
\text { Gingelly } \\
\text { seeds } \\
\text { Peanuts } \\
\text { Niger seeds } \\
\text { Jowar }\end{array}$ & $\begin{array}{l}100 \\
100 \\
100 \\
100 \\
30 \\
30 \\
30 \\
100\end{array}$ & 590 \\
\hline $\mathrm{V}_{3}$ & $\begin{array}{l}\text { Red rice } \\
\text { Sago } \\
\text { Roasted } \\
\text { Bengal gram } \\
\text { dhal } \\
\text { Green gram } \\
\text { dhal } \\
\text { Gingelly } \\
\text { seeds } \\
\text { Peanuts } \\
\text { Niger seeds } \\
\text { Bajra }\end{array}$ & $\begin{array}{l}100 \\
100 \\
100 \\
100 \\
30 \\
30 \\
30 \\
100\end{array}$ & 590 \\
\hline
\end{tabular}



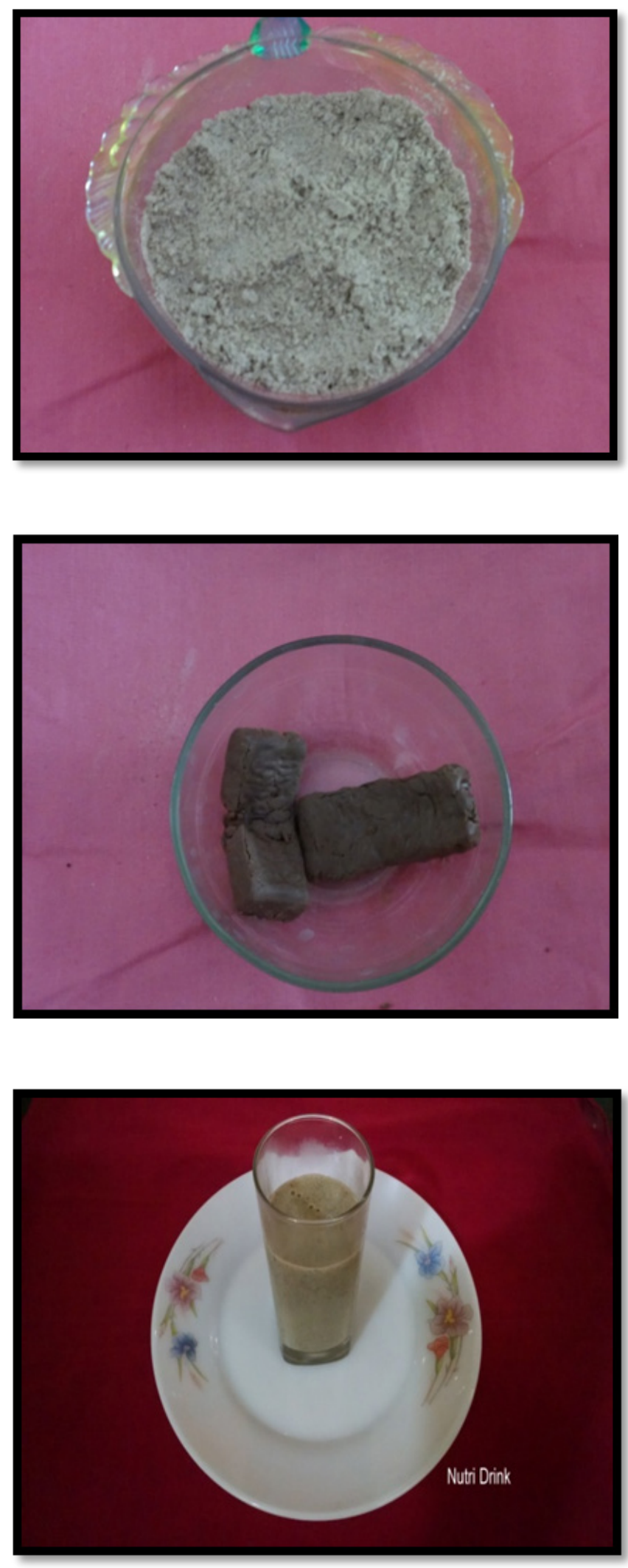

Figure 1. Pregame supplements formulated.

\subsection{Acceptability of the Nutrimix Powders}

Palatability is the ultimate criteria of any new food product developed. The palatability and acceptability of the nutrimix powders formulated were organoleptically evaluated by a panel of judges. For this purpose a panel was formulated with 10 well-trained nutrition experts, 10 athletes and 5 coaches. The products were numbered and presented for evaluation separately for each judge. The nutrimix powder was evaluated for its appearance, color, taste, mouth feel and flavor. Each criterion carried five scores and the products were evaluated for a total score of 25. A five point hedonic rating scale was used. The mean scores of the nutrimix powders developed are presented in (Table 2).

Variation one had obtained maximum score. Hence, this variation I of nutrimix powder was chosen to develop the pregame supplements.

\subsection{Formulation of Pregame Supplements}

The variation I of the nutrimix powder which had scored high in acceptability tests was incorporated into several recipes. Finally, three recipes were chosen to serve as pregame supplements (Figure 1). They were:

- Nutridrink which was in liquid form.

- Nutribar which had chewable consistency and

- Nutriball which had very soft mouth feel were selected for evaluation.

The composition, nutritive value and acceptability of these three supplements were organoleptically evaluated following the same evaluation procedure used in the development of nutrimix powders.

\section{Results and Discussion}

The results of the socio-economic status of the selected subjects was very low and food and nutrient intake was also not satisfactory. The selected athletes did not have adequate resources for purchase of any pregame nutrition supplements. Hence, a pregame supplement namely nutrimix powder was developed by the investigator which could be incorporated into different recipes.

The salient features of the nutrimix powder namely; nutrient, cost, shelf life, composition and acceptability were assessed and the results are presented and discussed in the following Tables. 
Table 2. Mean acceptability scores of the nutrimix powders

\begin{tabular}{|c|c|c|c|c|c|c|c|}
\hline \multirow{2}{*}{ Variations } & \multicolumn{5}{|c|}{ Organoleptic criteria } & \multirow{2}{*}{$\begin{array}{l}\text { Mean score } \\
\text { (Max. score } \\
25)\end{array}$} & \multirow{2}{*}{$\begin{array}{l}\text { Percentage } \\
\text { score }\end{array}$} \\
\hline & $\begin{array}{c}\text { Appearance } \\
\text { (5) }\end{array}$ & $\begin{array}{c}\text { Taste } \\
(5)\end{array}$ & $\begin{array}{c}\text { Texture } \\
(5)\end{array}$ & $\begin{array}{c}\text { Mouth feel } \\
\text { (5) }\end{array}$ & $\begin{array}{c}\text { Flavor } \\
(5)\end{array}$ & & \\
\hline I & 4 & 4 & 4 & 4 & 4 & 20 & 80 \\
\hline II & 3 & 3.5 & 3.5 & 4 & 3 & 17 & 68 \\
\hline III & 4 & 4 & 3.5 & 3.5 & 3 & 18 & 72 \\
\hline
\end{tabular}

Table 3. Nutrient composition and cost of the nutrimix powder

\begin{tabular}{|l|c|c|c|c|c|c|c|c|c|}
\hline $\begin{array}{l}\text { Variations } \\
\text { of } \\
\text { nutrimix }\end{array}$ & $\begin{array}{c}\text { Quantity } \\
(\mathbf{g})\end{array}$ & $\begin{array}{c}\text { Carbohydrate } \\
(\mathbf{g})\end{array}$ & $\begin{array}{c}\text { Energy } \\
(\mathrm{kca})\end{array}$ & $\begin{array}{c}\text { Fibre } \\
(\mathrm{Crude}) \\
(\mathrm{g})\end{array}$ & $\begin{array}{c}\text { Protein } \\
(\mathbf{g})\end{array}$ & $\begin{array}{c}\text { Fat } \\
(\mathbf{g})\end{array}$ & $\begin{array}{c}\text { Ca } \\
(\mathbf{m g})\end{array}$ & $\begin{array}{c}\text { Iron } \\
(\mathbf{m g})\end{array}$ & $\begin{array}{c}\text { Cost } \\
(\mathrm{Rs})\end{array}$ \\
\hline $\mathrm{V}_{1}$ & 100 & 65 & 441 & 3.7 & 17 & 13 & 221 & 15.4 & 8.77 \\
\hline $\mathrm{V}_{2}$ & 100 & 65 & 441 & 3.3 & 17 & 13 & 166 & 15.5 & 8.44 \\
\hline $\mathrm{V}_{3}$ & 100 & 65 & 441 & 3.3 & 17 & 13 & 166 & 14.8 & 8.77 \\
\hline
\end{tabular}

\subsection{Nutrient Composition and cost of the Nutrimix Powder Developed}

Table 3 presents the nutrient composition and cost of the three variations of the nutrimix powder developed.

As depicted in (Table 3), all the three variations of the nutrimix powder contained $65 \mathrm{~g}$ of carbohydrates and 440 kcals. The protein, fat and iron contents were equal in all the three variations while calcium was much higher in nutrimix $\mathrm{V}_{1}$. The cost of variations $\mathrm{V}_{1}$ and $\mathrm{V}_{3}$ were the same namely Rs.8.77 while the cost of $\mathrm{V}_{2}$ was slightly lower.

The excess calcium level in $\mathrm{V}_{1}$ variation was due to the presence of ragi. Ragi has $344 \mathrm{mg}$ of calcium per 100 g. The cost of nutrimix $V_{2}$ was low because of the low cost of jowar. But for these two factors all the other nutrients were equal in the three variations developed.

\subsection{Acceptability Scores of the Nutrimix Powders}

The mean acceptability scores of the nutrimix powders are presented in Table 1 in methodology. The results revealed that the variation $V_{1}$ with ragi had obtained maximum score of 20 out of 25 followed by $V_{3}$ with bajra (18) and $V_{2}$ with jowar (17). The acceptability of the nutrimix powder developed using ragi was high. This indicates that the taste of ragi was more acceptable compared to bajra and jowar. At the same time this variation had higher amount of calcium, which would benefits the athletes. Hence variation $V_{1}$ was selected for incorporating into the pregame sports supplements.

\subsection{Shelf Life of the Nutrimix Powder}

The most acceptable combination namely $\mathrm{V}_{1}$ with ragi was analyzed microbiologically for its keeping quality. Table 4, presents the microbial content of the nutrimix powder $\left(\mathrm{V}_{1}\right)$ before and after a storage period of three months.

The results of the microbial analysis of the nutrimix powder conducted in the fresh sample as well as sample stored for three months are presented in the (Table 4). This points out that there was no bacterial contamination in the fresh sample. Yeast and mould contents were below the detectable level. After a storage period of three months, yeast and mould count were below detectable level and bacterial count was 3000 (cfu/g). This was within the safe limits and does not have deleterious impact on health. The PFA act (1954) has recommended a total bacterial count of not more than 40,000 per gram of the sample

Table 4. Microbial content of the nutrimix powder

\begin{tabular}{|l|c|c|}
\hline Criteria & Initial & After 3 months \\
\hline $\begin{array}{l}\text { Total bacterial } \\
\text { count }(\mathrm{cfu} / \mathrm{g})\end{array}$ & Nil & 3000 \\
\hline Yeast & BDL & BDL \\
\hline Mould & BDL & BDL \\
\hline
\end{tabular}

BDL - Below Detectable Limit 
Table 5. Composition of the pregame supplements per $100 \mathrm{~g}$ of the supplements

\begin{tabular}{|l|c|c|c|}
\hline $\begin{array}{l}\text { Composition } \\
(\mathrm{g})\end{array}$ & Nutridrink & Nutribar & Nutriballs \\
\hline Nutrimix powder & 30 & 30 & 30 \\
\hline Milk & 40 & Nil & Nil \\
\hline Jaggery & 20 & 20 & 20 \\
\hline Glucose & 10 & 10 & 10 \\
\hline Banana & Nil & 30 & Nil \\
\hline Sago powder & Nil & Nil & 25 \\
\hline Ground nuts & Nil & 5 & Nil \\
\hline Niger seeds & Nil & 5 & 5 \\
\hline Ghee & Nil & Nil & 10 \\
\hline Total & 100 & 100 & 100 \\
\hline
\end{tabular}

in cereal based food products. Hence, the bacterial count of the nutrimix was within the recommended level for cereal products and therefore was found to be suitable for consumption.

\subsection{Characteristics of Nutrimix Incorporated Pregame Supplements}

The $V_{1}$ variation of the nutrimix powder was incorporated into three recipes namely nutridrink, nutribar and nutriballs as a pre game supplement for the athletes. Composition nutrient content and acceptability of pregame supplements developed are given in (Tables 3 and 4).

\subsubsection{Composition of the Pregame Supplements per $100 \mathrm{~g}$ of the Supplement}

From the (Table 5) it is observed that nutrimix powder $(30 \mathrm{~g})$, jaggery $(20 \mathrm{~g})$ and glucose $(10 \mathrm{~g})$ were the common ingredients added to all the three recipes. For nutridrink, milk was added and for nutribar, banana (30 g) ground nuts ( $5 \mathrm{~g}$ ) and niger seeds ( $5 \mathrm{~g}$ ) were added, for nutriball,
Table 7. Nutrient composition of pregame supplements

\begin{tabular}{|l|c|c|c|}
\hline Nutrients & $\begin{array}{c}\text { Nutridrink } \\
(\mathbf{2 0 0} \mathbf{~ m l})\end{array}$ & $\begin{array}{c}\text { Nutribar } \\
(\mathbf{1} \text { bar })\end{array}$ & $\begin{array}{c}\text { Nutriballs } \\
(\mathbf{2} \text { balls })\end{array}$ \\
\hline Energy (kcal) & 276 & 337 & 452 \\
\hline Carbohydrate $(\mathrm{g})$ & 32 & 40 & 53 \\
\hline Protein $(\mathrm{g})$ & 6 & 9 & 6 \\
\hline Fat $(\mathrm{g})$ & 6 & 8 & 16 \\
\hline Fibre $(\mathrm{g})$ & 1 & 1.7 & 1.5 \\
\hline Calcium $(\mathrm{mg})$ & 114 & 90 & 83 \\
\hline Iron $(\mathrm{mg})$ & 5.1 & 8.1 & 7.9 \\
\hline
\end{tabular}

sago, niger seeds and ghee were added. All the three recipes had equal weight of $100 \mathrm{~g}$. To bring the nutridrink to fluid consistency, $150 \mathrm{ml}$ water was added.

\subsubsection{Mean Acceptability Scores of Pregame Supplements}

It is evident from (Table 6) that the maximum score of 20 was obtained by nutridrink followed by nutribar. Hence, these two were chosen for supplementation. Nutridrink was preferred due to its good flavor color, acceptable mouth feel and was easy to consume. Nutribar had attractive brown color with appetizing banana flavor, soft mouth feel but took little more time to chew due to the content of nuts. Nutriballs scored less because of its sticky consistency and the flavor which was not acceptable.

Due to high acceptability scores nutridrink and nutribar were led to the selected athletes one hour before practice early in the morning.

\subsubsection{Nutrient Composition of Pregame Supplements}

Nutridrink supplied 276 (kcal), $32 \mathrm{~g}$ of carbohydrate, $6 \mathrm{~g}$ of protein, $6 \mathrm{~g}$ of fat, $1 \mathrm{~g}$ of fibre, the calcium content of nutridrink was $114 \mathrm{mg}$ which was high compare to nutribar and nutriballs. The iron content of nutridrink was $5.1 \mathrm{mg}$. The cost per portion of nutridrink was Rs. 5.74 .

Table 6. Mean acceptability scores of pregame supplements

\begin{tabular}{|l|c|c|c|c|c|c|c|}
\hline \multirow{2}{*}{ Variations } & \multicolumn{3}{|c|}{ Organoleptic criteria } & $\begin{array}{c}\text { Mean scores } \\
(\text { Max=25) }\end{array}$ & $\begin{array}{c}\text { Percentage } \\
\text { scores }\end{array}$ \\
\cline { 2 - 8 } & $\begin{array}{c}\text { Color \& } \\
\text { appearance (5) }\end{array}$ & Taste (5) & Mouthfeel (5) & $\begin{array}{c}\text { Consistency } \\
\text { (5) }\end{array}$ & Flavour (5) & 40 & 80 \\
\hline Nutri drink & 4 & 4 & 4 & 3.5 & 3 & 19 & 76 \\
\hline Nutribar & 4 & 4 & 3.5 & 3 & 3 & 16.5 & 66 \\
\hline Nutriballs & 4 & 3.5 & 3 & 4 & 3 & 20 \\
\hline
\end{tabular}


Nutribar supplied 337 (kcal), $40 \mathrm{~g}$ of carbohydrate, $9 \mathrm{~g}$ of protein, $6 \mathrm{~g}$ of fat, $1.7 \mathrm{~g}$ of fibre, the calcium content of nutribar was $90 \mathrm{mg}$. The iron content of nutribar was $8.1 \mathrm{mg}$. The cost per portion of nutribar was Rs. 5.78.

Nutriballs supplied 452 (kcal), $53 \mathrm{~g}$ of carbohydrate, $6 \mathrm{~g}$ of protein, $16 \mathrm{~g}$ of fat, $1.5 \mathrm{~g}$ of fibre, the calcium content of nutriballs was $83 \mathrm{mg}$. The iron content of nutriballs was $7.9 \mathrm{mg}$. The cost per portion of nutriballs was Rs. 11.23.

\section{Conclusion}

Due to high acceptability scores nutridrink and nutribar were chosen for supplementation to athletes early in the morning one hour before practice.

\section{References}

1. Sridevi Sivakami PL, Sarojini KS. Impact of nutritious supplement on selected anemic adolescents in Coimbatore city, Tamil Nadu. [Ph.D Thesis]. Submitted to Avinashilingam University for Women; 2008.

2. Indian Science Congress Association. Focal theme of the congress science and technology for indigeneous development in India. Kolkata: Indian Science Congress Association; 2016. p. 21.

3. Karnik S. Nutrition and diet therapy. Hyderabad: Biotech Pharma Publishers Private Limited; 2010. p. 2.

4. FAO. FAO STAT Agricultural Database. 2009. http:// faostat.fao.org 